\title{
CASP7 Gene
}

National Cancer Institute

\section{Source}

National Cancer Institute. CASP7 Gene. NCI Thesaurus. Code C28438.

This gene plays a role in the execution phase of apoptosis and is also involved in the regulation of lipogenic and cholesterogenic gene transcription. 